\title{
Does Insurance Market Activity Promote Economic Growth? A Cross-Country Study for Industrialized and Developing Countries
}

\author{
Marco Arena* \\ The World Bank
}

\begin{abstract}
Insurance market activity, both as a financial intermediary and a provider of risk transfer and indemnification, may contribute to economic growth by allowing different risks to be managed more efficiently and by mobilizing domestic savings. During the last decade, there has been faster growth in insurance market activity, particularly in emerging markets given the process of liberalization and financial integration, which raises questions about its impact on economic growth. This paper tests whether there is a causal relationship between insurance market activity (life and non-life insurance) and economic growth. Using the generalized method of moments for dynamic models of panel data for 56 countries and for the 1976-2004 period, we find robust evidence of a causal relationship between insurance market activity and economic growth. Both life and non-life insurance have a positive and significant causal effect on economic growth. High-income countries drive the results in the case of life insurance. On the other hand, both high-income and developing countries drive the results in the case of non-life insurance.
\end{abstract}

World Bank Policy Research Working Paper 4098, December 2006

The Policy Research Working Paper Series disseminates the findings of work in progress to encourage the exchange of ideas about development issues. An objective of the series is to get the findings out quickly, even if the presentations are less than fully polished. The papers carry the names of the authors and should be cited accordingly. The findings, interpretations, and conclusions expressed in this paper are entirely those of the authors. They do not necessarily represent the view of the World Bank, its Executive Directors, or the countries they represent. Policy Research Working Papers are available online at http://econ.worldbank.org.

\footnotetext{
* Operations and Policy Department (OPD), Financial Sector Vice-Presidency (FSEVP). I would like to thank the advice and support of Rodney Lester, Senior Advisor Capital and Risk Markets Group, in the preparation of this paper. I am also graceful to Thorsten Beck, César Calderón, Vidhi Chhaochharia, Stijn Claessens, and Kostas Tzioumis for their comments, feedback and suggestions on the preliminary results of this paper. Comments to the author are welcome: marena@worldbank.org
} 


\section{Introduction}

The last two decades have seen accelerated growth of insurance markets. Total world written real premiums increased by 82 percent between 1997 and 2004 (104 percent in the life insurance business and 60 percent in the non-life insurance one), from US\$ 1.6 trillion to US\$ 2.9 trillion. ${ }^{1}$ Emerging Markets (EMs) have recently experienced significantly faster real growth of their insurance sectors than industrialized countries (52 percent versus 27 percent between 1997 and 2004), reflecting liberalization and financial integration after the implementation of structural reforms. ${ }^{2}$

Insurance market activity, both as financial intermediary and as provider of risk transfer and indemnification, may promote economic growth by allowing different risks to be managed more efficiently encouraging the accumulation of new capital, and by mobilizing domestic savings into productive investments. In this context, the evidence mentioned above raises questions regarding the impact that the faster growth of insurance activity would have on economic growth.

So far, most of the empirical work has assessed the impact of the banking sector and stock market development on economic growth (Levine, 2004). However, even though the potential contribution of the insurance market activity on economic growth has been recognized, the assessment of a potential causal relationship between insurance market activity and economic growth has not been as extensively studied as that of banks. This reflects both data availability and the rather arcane reputation of the sector in economic circles.

In this context, the purpose of the present paper is to provide a systematic assessment of the causal effect of insurance market activity on economic growth, taking into account the different effects that life and non-life insurance could have due to the different benefits that they provide to households and corporations. To accomplish this task we use measures of insurance premiums as proxies of insurance activity for a set of 56 countries over the 1976-2004 period and use an estimation method that is suited to panel data, and accounts for some endogeneity in the explanatory variables. This is the generalized method of moments (GMM) for dynamic models of panel data developed by Arellano and Bond (1991) and Arellano and Bover (1995).

Among our main results we found robust evidence of a causal relationship of insurance market activity on economic growth. Both life and non-life insurance premiums have a positive and significant effect on economic growth. We also found evidence that in the case of life insurance, the impact on economic growth is driven by high-income countries only. On the other hand, in the case of non-life insurance, its impact is driven by both high-income and developing (middle and low-income) countries. However, the results

\footnotetext{
${ }^{1}$ Author's calculations based on premium data collected and published by Swiss Re.

${ }^{2}$ Even though the faster growth in insurance market activity has taken place in EMs, the absolute real written premium numbers are larger for industrialized countries (US\$ 2.6 trillion versus US\$ 0.3 trillion for the year 2004 only).
} 
suggest that non-life insurance has a larger effect in high-income countries than in developing ones.

The paper is organized as follows. Section 2 presents a summary of the relationship between insurance market activity and economic growth. In section 3 , we provide a review of the empirical literature. Sections 4 and 5 describe the methodology and data respectively. Section 6 presents and interprets the results, and section 7 offers some conclusions.

\section{Insurance market activity and economic growth}

A large body of theoretical literature has emphasized how financial systems influence savings and investment decisions and hence long-run growth rates through the following functions (i) lowering the costs of researching potential investments, (ii) exerting corporate governance, (iii) trading, diversification, and management of risk, (iv) mobilization and pooling of savings, (v) conducting exchanges of goods and services, and (vi) mitigating the negative consequences that random shocks can have on capital investment (Levine, 2004). Financial intermediaries support development through the improvement of these functions (i.e., the amelioration of market frictions such as the costs of acquiring information, making transactions, and enforcing contracts and allowing economies to more efficiently allocate resources (savings) across investments). However, the positive effects of financial development are tailored by the macro policies, laws, regulations, financial infrastructures and enforcement norms applied across countries and time.

The insurance activity, both as a provider of risk transfer and indemnification and as an institutional investor, may contribute to economic growth in the following ways (i) promoting financial stability, (ii) facilitating trade and commerce (the most ancient insurance activity), (iii) mobilizing domestic savings, (iv) allowing different risks to be managed more efficiently encouraging the accumulation of new capital, (v) fostering a more efficient allocation of domestic capital, and (vi) helping to reduce or mitigate losses (Skipper, 1997, p. 2-7). In addition, there are likely to be different effects on economic growth from life and non-life insurance (property / liability) given that these two type of insurance protect the households and corporations from different kind of risks that affect the economic activity in different ways and also because life insurance companies facilitate long-term investments rather than short-term investments as it is the case of non-life insurance companies.

At the empirical level, most of the extant work assesses the impact of the banking sector on economic growth showing that banking sector development contributes to explain economic growth (King and Levine, $1993 \mathrm{a}$, b) and that there is a positive causal relationship between banking sector development and economic growth (Levine, 1998, 1999; Levine, Loayza, and Beck, 2000). Also, the impact of the stock market development together with that of the banking sector on economic growth has been studied by Levine and Zervos (1998), showing that initial measures of stock market 
liquidity and banking sector development are both strong predictors of economic growth over the next 18 years, and by Beck and Levine (2004) who show that stock markets and banks have a positive causal relationship with economic growth.

However, the impact of insurance market activity on economic growth has not been studied as extensively as the role of the banking sector and the stock market. ${ }^{3}$ In this context, the main task of our paper is to assess whether insurance market activity influences economic growth distinguishing the particular effects of life and non-life insurance activity. Even though it is recognized that insurance activity not only would have an effect on economic growth as a provider of risk and indemnification but also as an institutional investor by mobilizing savings, we will assess the effect of insurance on economic growth only as a provider of risk and indemnification due to data limitations, which are explained below.

Insurance market activity may not only contribute to economic growth by itself but also through complementarities with the banking sector and the stock market. In the first case, the conjoint effect with the banking sector, the development of insurance activity could encourage bank borrowing by reducing companies' market cost of capital, which influences economic growth by increasing the demand for financial services (Grace and Rebello, 1993). Also, property insurance may facilitate bank intermediation activity by for example partially collateralizing credit, which would reduce bank's credit risk exposures promoting higher levels of lending (Zou and Adams, 2006). At the same time, the development of the banking sector may facilitate the development of the insurance activity through a much more effective payment system allowing an improved financial intermediation of services (Webb, Grace, and Skipper, 2002). Regarding the conjoint effect with the stock market, the development of the insurance activity, in particular life insurance companies, could promote stock market development by investing funds (savings) raised through contractual saving products in stocks and equities (Impavido, et al. 2003; USAID, 2006). In this context, the second task of our paper is to assess whether the measures of insurance market activity (life and non-life) are complementary or not to the measures of banking sector and stock market development in order to test if banks, stock markets and insurers complement each other.

\section{Review of the empirical literature}

The assessment of a potential causal relationship between insurance market activity and economic growth has not been extensively studied. Exceptions are the work of Ward and Zurbruegg (2000), Webb et al. (2002), Kugler and Ofoghi (2006), and Adams, Andersson, Andersson, and Lindmark (2006). ${ }^{4}$ Ward and Zurbruegg (2000) examine the potential causal relationship between economic growth and insurance market activity for

\footnotetext{
${ }^{3}$ Exceptions are Ward and Zurbruegg (2000), Webb et al. (2002), Kugler and Ofoghi (2005), and.Adams, Andersson, Andersson, and Lindmark (2005).

${ }^{4}$ Previous work, like Outreville (1990), show that insurance development, proxied by the ratio of total written premiums to GDP, is strongly correlated with GDP per capita and financial development, proxy by the ratio of M2 to GDP. However, as the author pointed out, a study of the causal link between insurance development and economic growth is lacking.
} 
nine OECD countries for the period 1961-1996, using annual real GDP as a measure of economic activity and annual real total written premiums as a measure of insurance activity. ${ }^{5}$ The authors use the VAR-error correction methodology on a country-bycountry basis finding the presence of a long-run relationship for five countries (Australia, Canada, France, Italy, and Japan). In order to assess causation between insurance and GDP growth for four countries (Australia, Canada, Italy, and Japan), the authors test the statistical significance of the coefficients on insurance in the long-run equation. By testing the significance of the coefficients on insurance in the short-run equation, the authors only find causation for three countries (Australia, Canada, and Japan).

Webb, et. al (2002) examine the causal relationship of banks, life, and non-life insurance activity on economic growth in the context of a revised Solow-Swan neoclassical of economic growth model, where the authors include financial activities (bank, life and non-life insurance) as an additional input in the production function assumed to be a Cobb-Douglas type. The empirical specification falls in the context of the cross-country economic growth regressions literature (Sala-i-Martin, 1995), where the growth rate of real GDP per capita is regressed against the change in capital intensity (gross domestic investment), human capital (education enrollment), the ratio of government consumption to GDP, the degree of openness (the ratio of exports to GDP), the initial level of GDP per capita, and measures of financial intermediary activity (the ratio of bank credit to GDP, the ratio of non-life insurance premiums to GDP, and the ratio of life insurance premiums to GDP). For the estimation, the authors use the three-stage-least-squares instrumental variable approach (3SLS-IV), where the instruments used are the legal origin of the country (English, French, German, Scandinavian, or Socialist) for the banking measure, a measure of corruption and quality of the bureaucracy for the non-life insurance measure, and the religious composition of the country (Catholic, Muslim, or Protestant) for the life insurance measure. In order to assess a causal relationship with economic growth, the authors use average levels the explanatory variables. ${ }^{6}$

Among the main findings, the authors show that the exogenous components of the banking and life insurance measures are found to be robustly predictive of increased economic growth. However, these measures are not significant in the presence of interaction terms between banking and life insurance, and between banking and non-life insurance; when these interaction terms are included, the individual variables loss explanatory power. The latter result would suggest the presence of complementarities among financial intermediaries.

Kugler and Ofoghi (2005) evaluate both a long-run relationship and Granger-causality between insurance market size and economic growth for the United Kingdom using net written premium for each insurance market (general and long-term insurance) in the UK

\footnotetext{
${ }^{5}$ The authors also include a number of explanatory variables in the analysis like changes in private saving rates, the general government budget surplus, population size, the general government level of current expenditure, and youth plus old age dependency ratio (proportion of the total population under 16 and over 65 years of age).

${ }^{6}$ The average is done for the period 1980-1996. A total of 55 countries are included in their study.
} 
for the period 1966-2003. Using Johansen's cointegration test, the authors find a long-run relationship between development in insurance market size and economic growth for all insurance components. ${ }^{7}$ Regarding causality tests, there is evidence of long-run causality from growth in insurance market size to GDP growth for eight out of nine insurance categories that are considered. ${ }^{8}$ Short-run causality exits from life, liability and pecuniary loss insurance. As the authors point out in the paper, these results do not permit to make a definitive conclusion regarding causality.

Adams et al. (2005) examine empirically the dynamic historical relation between banking, insurance and economic growth in Sweden using time-series data from 1830 to 1998 using cointegration and Granger causality tests. Their results indicate that the development of banking, but not insurance (measure by total insurance premiums), preceded economic growth in Sweden during the nineteenth century, while Grangercausality was reverse in the twentieth century. The insurance market appears to be driven more by the pace of growth in the economy rather than leading economic development.

Our paper, as opposed to that of Ward and Zurbruegg and Adams et al., uses not only data on total insurance premiums but also its desegregation into life and non-life insurance premiums in order to assess their potential different effects on economic growth. Also, we use a broader set of countries, industrialized and developing, to evaluate whether there are similar underlying patterns among different groups of income countries. In this sense, our paper is close to that of Webb et al. However, we depart from it given that we use not only cross-country data but also time series data to exploit the additional information provided by the over-time variation in the growth rate and its determinants, which allows for more precise estimates.

\section{Methodology}

As in Webb et al., this paper evaluates the effect of insurance variables on economic growth within the context of the standard growth regressions specification. The general regression equation to be estimated is the following

(1) $y_{i, t}=\beta^{\prime} X_{i, t}+\mu_{t}+\eta_{i}+\xi_{i, t}$ where the subscripts $i, t$ represent country and time period, respectively. $y$ is the dependent variable of interest, that is, economic growth. $X$ is a set of time- and country-varying explanatory variables, proxies of banking, stock market and insurance market development, interaction terms, and control variables, while $\beta$ is the vector of coefficients to be estimated. Finally, $\mu_{t}$ is an unobserved time-specific effect, $\eta_{i}$ is an unobserved country specific effect, and $\xi$ is the error term.

\footnotetext{
${ }^{7}$ The authors do not include in the analisis additional explanatory variables as in the paper of Ward and Zurbruegg (2000)

${ }^{8}$ The categories are: life, motor, accident and health, property, liability, pecuniary loss, reinsurance, and Marine-Aviation-Transport insurance.
} 
We work with a pooled data set of cross-country and time-series observations (data details are given below). This paper uses an estimation method that is suited to panel data, deals with static or dynamic regression specifications, controls for unobserved timeand country specific effects, and accounts for some endogeneity in the explanatory variables. This is the generalized method of moments (GMM) for dynamic models of panel data developed by Arellano and Bond (1991) and Arellano and Bover (1995).

The method deals with unobserved time effects through the inclusion of period specific intercepts. Dealing with unobserved country effects is not as simple given the possibility that the model is dynamic and contains endogenous explanatory variables. Thus unobserved country-effects need to be controlled for by differencing and instrumentation. Likewise, the method relies on instrumentation to control for joint endogeneity. Specifically, it allows relaxing the assumption of strong exogeneity of the explanatory variables by allowing them to be correlated with current and previous realizations of the error term $\xi$.

Parameter identification is achieved by assuming that future realizations of the error term do not affect current values of the explanatory variables, that the error term $\xi$ is serially uncorrelated, and that changes in the explanatory variables are uncorrelated with the unobserved country-specific effect. As Arellano and Bond (1991) and Arellano and Bover (1995) show, this set of assumptions generates moment conditions that allow estimation of the parameters of interest. The instruments corresponding to these moment conditions are appropriately lagged values of both levels and differences of the explanatory and dependent variables (the latter if the model is dynamic). In addition, we use as instruments of banking and stock market variables the origin of the legal code (English, French, German, Socialist or Scandinavian), and measures of religious composition as instruments of insurance variables. Since typically the moment conditions over-identify the regression model, they also allow for specification testing through a Sargan-type test.

\section{Data}

We estimate economic growth regressions on a pooled (cross-country, time-series) data set consisting of 56 countries and, for each of them, at most 6 non-overlapping five-year periods over 1976-2004. See Appendix 1 for the list of countries in the sample. ${ }^{9}$ Appendix 2 provides full definitions and sources of all variables used in the paper, and Tables 1 and 2 present basic descriptive statistics and correlations for the data used in the regressions.

\footnotetext{
Data availability has mainly determined the selected countries. It was required that the country has a t least fifteen years of continuous data.
} 
Table 1: In Sample Descriptive Statistics

\begin{tabular}{lrrrr}
\hline Variable & Mean & $\begin{array}{c}\text { Standard } \\
\text { Deviation }\end{array}$ & Minimum & Maximum \\
\hline Life & 0.021 & 0.025 & 0.000 & 0.136 \\
Non-Life & 0.022 & 0.015 & 0.003 & 0.130 \\
(Life + Non-Life) & 0.042 & 0.033 & 0.005 & 0.179 \\
Private Credit & 0.512 & 0.336 & 0.042 & 1.629 \\
Stock Market Turnover & 0.424 & 0.509 & 0.004 & 3.508 \\
GDP per capita growth & 0.019 & 0.021 & -0.065 & 0.091 \\
Openness & 0.040 & 0.005 & 0.026 & 0.054 \\
Gov. Consumption & 0.027 & 0.003 & 0.014 & 0.034 \\
Inflation & 0.334 & 1.863 & -0.005 & 23.422 \\
Human Capital & 0.736 & 0.304 & 0.077 & 1.607 \\
Terms of Trade changes & 0.002 & 0.035 & -0.110 & 0.205 \\
Log initial GDP per capita & 9.062 & 0.957 & 6.605 & 10.439 \\
\hline
\end{tabular}

As it is standard in the economic growth literature, the dependent variable is the average rate of real per capita GDP growth. The regression equation is dynamic in the sense that it includes the initial level of per capita GDP as an explanatory variable. As additional control variables, the regression includes the average rate of secondary school enrollment to account for human capital investment, the average inflation rate to account for monetary discipline, the average growth of the terms of trade ratio, and the average ratio of government consumption to GDP as a measure of government burden. Following Beck and Levine (2004), we measure banking sector development using the ratio of bank claims on the private sector by deposit money banks divided by GDP. This measure excludes credits by development banks and loans to the government and public enterprises. Regarding stock market development, the turnover ratio measure of market liquidity is use as a proxy. The latter equals the value of the trades of shares on domestic exchanges divided by the total value of listed shares. 
Table 2: In-Sample Correlations

\begin{tabular}{|c|c|c|c|c|c|c|c|c|c|c|c|}
\hline & Life & Non-Life & (Life + Non-Life) & Private Credit & $\begin{array}{c}\text { Stock Market } \\
\text { Turnover }\end{array}$ & $\begin{array}{l}\text { GDP per capita } \\
\text { growth }\end{array}$ & Openness & Gov. Consumption & Inflation & Human Capital & $\begin{array}{c}\text { Terms of Trade } \\
\text { changes }\end{array}$ \\
\hline Life & 1 & & & & & & & & & & \\
\hline \multirow[t]{2}{*}{ Non-Life } & 0.427 & 1 & & & & & & & & & \\
\hline & 0.000 & & & & & & & & & & \\
\hline \multirow[t]{2}{*}{$($ Life + Non-Life) } & 0.935 & 0.720 & 1 & & & & & & & & \\
\hline & 0.000 & 0.000 & & & & & & & & & \\
\hline \multirow[t]{2}{*}{ Private Credit } & 0.520 & 0.413 & 0.562 & 1 & & & & & & & \\
\hline & 0.000 & 0.000 & 0.000 & & & & & & & & \\
\hline \multirow[t]{2}{*}{ Stock Market Turnover } & 0.216 & 0.050 & 0.200 & 0.222 & 1 & & & & & & \\
\hline & 0.000 & 0.342 & 0.000 & 0.000 & & & & & & & \\
\hline \multirow[t]{2}{*}{ GDP per capita growth } & 0.132 & 0.021 & 0.110 & 0.146 & 0.106 & 1 & & & & & \\
\hline & 0.007 & 0.677 & 0.026 & 0.000 & 0.030 & & & & & & \\
\hline \multirow[t]{2}{*}{ Openness } & 0.144 & 0.121 & 0.160 & 0.220 & -0.052 & 0.145 & 1 & & & & \\
\hline & 0.003 & 0.013 & 0.001 & 0.000 & 0.290 & 0.000 & & & & & \\
\hline \multirow[t]{2}{*}{ Gov. Consumption } & 0.156 & 0.308 & 0.239 & 0.231 & -0.009 & -0.062 & 0.373 & 1 & & & \\
\hline & 0.001 & 0.000 & 0.000 & 0.000 & 0.859 & 0.064 & 0.000 & & & & \\
\hline \multirow[t]{2}{*}{ Inflation } & -0.094 & -0.008 & -0.075 & -0.116 & -0.006 & -0.275 & -0.067 & -0.009 & 1 & & \\
\hline & 0.058 & 0.874 & 0.127 & 0.001 & 0.908 & 0.000 & 0.054 & 0.799 & & & \\
\hline \multirow[t]{2}{*}{ Human Capital } & 0.573 & 0.472 & 0.623 & 0.682 & 0.289 & 0.225 & 0.176 & 0.402 & -0.080 & 1 & \\
\hline & 0.000 & 0.000 & 0.000 & 0.000 & 0.000 & 0.000 & 0.000 & 0.000 & 0.079 & & \\
\hline \multirow[t]{2}{*}{ Terms of Trade changes } & -0.050 & -0.030 & -0.051 & -0.044 & -0.094 & -0.024 & -0.006 & -0.059 & -0.031 & -0.080 & 1 \\
\hline & 0.339 & 0.556 & 0.329 & 0.284 & 0.065 & 0.533 & 0.883 & 0.120 & 0.437 & 0.089 & \\
\hline
\end{tabular}

P-values in italics.

The explanatory variables of interest are measures of insurance market development proxied by the ratio of life insurance premiums to GDP and the ratio of non-life (property-liability) insurance premiums to GDP. These measures could be considered as measures of penetration of insurance activity in the economy. ${ }^{10}$ However, the use of premiums as a proxy for insurance market activity would only capture the role of life and non-life insurance companies as providers of risk transfer and indemnification not their role as institutional investors. Given data limitations, it is currently not possible to have a consistent time series of the ratio of financial investments (assets) to GDP, which would capture their role as institutional investors ${ }^{11}$. Finally, the regression equation also allows for both unobserved time-specific and country-specific effects.

\footnotetext{
${ }^{10}$ Life and non-life business are categorized in accordance with standard EU and OECD conventions. In this framework accident and health insurance are seen as belonging to non-life insurance, regardless of how these lines are classified in the individual countries (Sigma, 2005, p.30).

${ }^{11}$ Such data is only available for OECD countries and for limited periods.
} 


\section{Results}

\subsection{Linear Effects of Insurance Market Activity}

Table 3, columns 1 and 2, shows the linear effects of private credit and stock market turnover on economic growth. The coefficients of both variables are positive and statistically significant reflecting that the proxies for banking sector and stock market development have a causal effect on economic growth, which is consistent with previous findings in the literature (Levine, 2004; Beck and Levine, 2004). Columns 3-5 show the individual and joint effect of life and non-life premiums to GDP on economic growth. The coefficients of the insurance variables are positive and statistically significant. This result suggests that the proxies used for insurance market activity (life and non-life premiums to GDP) have a causal effect on economic growth both individually and jointly. The coefficient on stock market turnover is positive and statistically significant in all specifications. However, the coefficient on private credit to GDP is not significant in the specifications that include insurance variables. The latter could be explained by a significant statistical correlation between private credit to GDP and the insurance variables (between 0.41 and 0.56 ), which would not allow the proxy of banking sector development to convey additional information.

Regarding the individual impact of insurance variables, an increase in one standard deviation in life insurance premiums to GDP, ceteris paribus, would imply an increase of 0.37 percent in economic growth. In the case of non-life insurance premiums to GDP, an increase of one standard deviation would have a larger impact on economic growth of 0.39 percent. Finally, a one standard deviation increase in total insurance (life plus nonlife insurance premiums to GDP) would increase real GDP per capita growth by 0.47 percent.

With respect to the rest of control variables, the coefficients on the degree of openness the change in the terms of trade, and the initial measures of human capital are positive and statistically significant, and the coefficients on government consumption, inflation, and initial GDP per capita are negative and significant. The Sargan and serial-correlation tests do not reject the null hypothesis of correct specification, lending support to our estimation results. 
Table 3: Linear Effects of Insurance Variables on Economic Growth Sample of 56 countries, 1976-2004 (5-year period observations)

Dependent Variable: Growth in real GDP per capita

Estimation Method: GMM-IV System Estimator

\begin{tabular}{|c|c|c|c|c|c|}
\hline & [1] & [2] & [3] & [4] & [5] \\
\hline \multirow[t]{2}{*}{ Constant } & $0.115^{\star \star \star}$ & $0.127^{* * *}$ & $0.162^{\star \star \star}$ & $0.151^{\star * *}$ & $0.151^{\star * *}$ \\
\hline & 0.000 & 0.000 & 0.000 & 0.000 & 0.000 \\
\hline \multirow[t]{2}{*}{ Log. Initial GDP per capita } & $-0.009^{* * *}$ & $-0.012 * * *$ & $-0.015^{* * *}$ & $-0.015^{* \star \star}$ & $-0.014^{* * *}$ \\
\hline & 0.001 & 0.000 & 0.000 & 0.000 & 0.000 \\
\hline \multirow[t]{2}{*}{ Private Credit to GDP } & $0.010 * *$ & $0.007 * *$ & -0.003 & -0.005 & 0.002 \\
\hline & 0.014 & 0.033 & 0.650 & 0.476 & 0.755 \\
\hline \multirow[t]{2}{*}{ Stock Market Turnover } & & $0.026 * * \star$ & $0.025 * \star *$ & $0.026 * \star *$ & $0.025 * * *$ \\
\hline & & 0.000 & 0.000 & 0.000 & 0.000 \\
\hline \multirow[t]{2}{*}{ (Life + Non-Life insurance) to GDP } & & & 0.138 *** & & \\
\hline & & & 0.000 & & \\
\hline \multirow[t]{2}{*}{ Life premiums to GDP } & & & & $0.151 * \star$ & \\
\hline & & & & 0.050 & \\
\hline \multirow[t]{2}{*}{ Non-Life premiums to GDP } & & & & & $0.251 * * *$ \\
\hline & & & & & 0.000 \\
\hline \multirow[t]{2}{*}{ Degree of openess } & $0.399^{* * *}$ & $0.598 * * *$ & $0.501 *$ & $0.564^{* *}$ & 0.313 \\
\hline & 0.001 & 0.004 & 0.060 & 0.019 & 0.146 \\
\hline \multirow[t]{2}{*}{ Governement consumption } & $-1.858^{* \star \star}$ & $-1.679 * * *$ & $-2.206^{* \star *}$ & $-1.889 * * *$ & $-1.988^{* * *}$ \\
\hline & 0.000 & 0.000 & 0.000 & 0.000 & 0.000 \\
\hline \multirow[t]{2}{*}{ Inflation } & $-0.003^{* * *}$ & $-0.003 * * *$ & $-0.003^{* * *}$ & $-0.003 * * *$ & $-0.003^{* * *}$ \\
\hline & 0.000 & 0.000 & 0.000 & 0.000 & 0.000 \\
\hline \multirow[t]{2}{*}{ Terms of trade } & $0.024^{* * *}$ & $0.046^{* * *}$ & $0.043^{* * *}$ & $0.041^{* * *}$ & $0.048^{* * *}$ \\
\hline & 0.003 & 0.000 & 0.000 & 0.000 & 0.000 \\
\hline \multirow[t]{2}{*}{ Human Capital Investment } & $0.042^{\star \star \star}$ & $0.037^{* * *}$ & $0.055^{* \star *}$ & $0.054^{\star \star \star}$ & $0.057^{* * *}$ \\
\hline & 0.000 & 0.000 & 0.000 & 0.000 & 0.000 \\
\hline \multicolumn{6}{|l|}{ Period shifts } \\
\hline Period 81-85 & $-0.016^{* * *}$ & $-0.016^{* * *}$ & $-0.015^{* * *}$ & $-0.015^{* * *}$ & $-0.016^{* * *}$ \\
\hline Period 86-90 & $-0.007^{\star * *}$ & $-0.011^{* * *}$ & $-0.012 * \star *$ & $-0.012 * * *$ & $-0.012^{* * *}$ \\
\hline Period 91-95 & $-0.017^{\star \star \star}$ & $-0.020 * * *$ & $-0.023^{\star \star \star}$ & $-0.023^{* \star *}$ & $-0.024^{* \star *}$ \\
\hline Period 96-00 & $-0.017^{* * *}$ & $-0.023 * * *$ & $-0.027^{* * *}$ & $-0.027^{* * *}$ & $-0.027^{* * *}$ \\
\hline Period 01-04 & $-0.027^{* * *}$ & $-0.033^{* \star *}$ & $-0.040^{* * *}$ & $-0.038^{* * *}$ & $-0.039^{* * *}$ \\
\hline Countries & 56 & 56 & 56 & 56 & 56 \\
\hline Observations & 263 & 263 & 263 & 263 & 263 \\
\hline \multicolumn{6}{|l|}{ Specification tests ( $p$-values) } \\
\hline -Sargan test & 0.732 & 0.766 & 0.448 & 0.447 & 0.525 \\
\hline -2nd. Order Correlation & 0.252 & 0.586 & 0.425 & 0.429 & 0.484 \\
\hline
\end{tabular}

P-values in Italics. ${ }^{* * *},{ }^{* *},{ }^{*}$ denote statistical significance at the 1,5 , and 10 percent level.

In addition, Table 4 shows the coefficients of life and non-life insurance premiums to GDP by income group. In the case of life insurance, only high-income countries would drive the results shown in Table 3 because the coefficient on life insurance for developing countries is not significant. An increase in one standard deviation in life insurance premiums to GDP in high-income countries only, ceteris paribus, would imply an 
increase of 0.58 percent in economic growth in high-income countries. In the case of nonlife insurance, the results shown in Table 3 are driven not only by high-income countries but also by developing countries. However, the effect of non-life insurance premiums to GDP is larger in high-income countries. An increase in one standard deviation in non-life insurance premiums to GDP in high-income countries (developing countries), ceteris paribus, would imply an increase of $0.53(0.25)$ percent in economic growth in highincome countries (developing countries).

Table 4: Coefficients on Life and Non-Life Insurance by Income Group

\begin{tabular}{|c|c|c|c|c|c|}
\hline High-Income countries & & & Developing countries $^{1}$ & & \\
\hline Variable & Coefficient & T-Stat & Variable & Coefficient & T-Stat \\
\hline Life & 0.018 & 0.213 & Life & 0.249 & 2.546 \\
\hline Life* High Income dummy & 0.231 & 1.827 & Life* Dev. Countries dummy & -0.231 & 1.827 \\
\hline Linear combination & 0.246 & 2.500 & Linear combination & 0.018 & 0.213 \\
\hline Non-Life & 0.168 & 3.827 & Non-Life & 0.533 & 2.500 \\
\hline Non-Life* High Income dummy & 0.365 & 1.690 & Non-Life* Dev. Countries dummy & -0.265 & 1.690 \\
\hline Linear combination & 0.533 & 2.500 & Linear combination & 0.168 & 3.827 \\
\hline
\end{tabular}

\subsection{Non-linear Effects of Insurance Market Activity}

This paper also evaluates the possibility that insurance variables (life and non-life premiums to GDP) could have non-linear effects on economic growth. Table 5 presents the results of the economic growth regressions including a quadratic term for the insurance variables. With respect to life insurance, the results show that the coefficients of the linear and quadratic term are positive but not significant. Regarding non-life insurance, the coefficient of the linear term is negative but not significant, and the coefficient of the quadratic term is positive but not significant. However, a potential explanation for these results would be the high correlation between the variable and its squared, which is 0.92 in the case of life insurance premiums to GDP and 0.96 in the case of non-life insurance premiums to GDP. 
Table 5: Non-Linear Effects of Insurance Variables

Sample of 56 countries, 1976-2004 (5-year period observations)

Dependent Variable: Growth in real GDP per capita

Estimation Method: GMM-IV System Estimator

[1]

Life insurance

[2]

\begin{tabular}{|c|c|c|}
\hline & Life insurance & Non-Life insurance \\
\hline \multirow[t]{2}{*}{ Constant } & $0.129 * * *$ & $0.098^{* * *}$ \\
\hline & 0.000 & 0.000 \\
\hline \multirow[t]{2}{*}{ Private Credit to GDP } & -0.005 & 0.008 \\
\hline & 0.527 & 0.254 \\
\hline \multirow[t]{2}{*}{ Stock Market Turnover } & $0.024 * * *$ & $0.023 * * *$ \\
\hline & 0.000 & 0.000 \\
\hline \multirow[t]{2}{*}{ Insurance } & 0.009 & -0.985 \\
\hline & 0.947 & 0.164 \\
\hline \multirow[t]{2}{*}{ Insurance ${ }^{2}$} & 1.423 & 9.911 \\
\hline & 0.113 & 0.386 \\
\hline \multicolumn{3}{|l|}{ Control Variables } \\
\hline \multirow[t]{2}{*}{ Log. Initial GDP per capita } & $-0.013 * * *$ & $-0.010 * * *$ \\
\hline & 0.000 & 0.000 \\
\hline \multirow[t]{2}{*}{ Degree of openess } & $0.934^{* * *}$ & 0.540 \\
\hline & 0.007 & 0.117 \\
\hline \multirow[t]{2}{*}{ Governement consumption } & $-1.779 * * *$ & $-0.894^{* *}$ \\
\hline & 0.000 & 0.054 \\
\hline \multirow[t]{2}{*}{ Inflation } & $-0.003^{* * *}$ & $-0.003^{* * *}$ \\
\hline & 0.000 & 0.000 \\
\hline \multirow[t]{2}{*}{ Terms of trade } & $0.050^{* * *}$ & $0.051^{* * *}$ \\
\hline & 0.000 & 0.000 \\
\hline \multirow[t]{2}{*}{ Human Capital Investment } & $0.046^{* * *}$ & $0.044^{* * *}$ \\
\hline & 0.000 & 0.000 \\
\hline \multicolumn{3}{|l|}{ Period shifts } \\
\hline Period 81-85 & $-0.014 * * *$ & $-0.016 * * *$ \\
\hline Period 86-90 & $-0.010^{* * *}$ & $-0.010 * * *$ \\
\hline Period 91-95 & $-0.021^{* * *}$ & $-0.019 * * *$ \\
\hline Period 96-00 & $-0.025 * * *$ & $-0.023 * * *$ \\
\hline Period 01-04 & $-0.036 * * *$ & $-0.035 * * *$ \\
\hline Countries & 56 & 56 \\
\hline Observations & 263 & 263 \\
\hline \multicolumn{3}{|l|}{ Specification tests ( $p$-values) } \\
\hline -Sargan test & 0.615 & 0.604 \\
\hline -2nd. Order Correlation & 0.642 & 0.783 \\
\hline
\end{tabular}

P-values in Italics. ${ }^{* * *},{ }^{* \star},{ }^{*}$ denote statistical significance at the 1,5 , and 10 percent level. 


\subsection{Complementarities between insurance and banking and stock market variables}

To assess whether the measures of insurance activity (life and non-life premiums to GDP) are complementary or not to measures of bank intermediation (private credit to GDP) and stock market (stock market turnover) an interaction term is included in the growth regressions. Table 6, columns 1 to 3 , shows the results of the interaction between insurance variables and private credit. The coefficient of the interaction term is negative and significant in all specifications; i.e., these results would suggest that banking sector intermediation and insurance measures (life and non-life premiums to GDP) are substitutes rather than complements. The impact on economic growth of one standard deviation increase in private credit to GDP and life insurance premiums to GDP, approximately 2.38 percent, would be ameliorated in 0.7 percent by the negative interaction. ${ }^{12}$ In the case of private credit and non-life insurance (total insurance: life and non-life insurance premiums), the joint impact on economic growth, 1.45 percent (2.43 percent), would be ameliorated in 0.42 per cent ( 0.62 percent).

Regarding the interaction between stock market turnover and insurance variables, the sign of the interaction is negative, which would also suggest a substitution effect. The impact on economic growth of one standard deviation increase in stock market turnover and life insurance premiums to GDP, approximately 1.84 percent, would be ameliorated in 0.2 percent by the negative interaction. In the case of stock market turnover and nonlife insurance (total insurance: life and non-life insurance premiums), the joint impact on economic growth, 2.14 per cent (1.98 percent), would be ameliorated in 0.25 percent (0.21 percent).

Even though the sum of the individual contributions on economic growth of insurance variables, private credit and stock market turnover are significant, caution is needed in the interpretation of the results, specially the sign of the interaction term, due to collinearity issues. The interaction terms in all the previous regressions are correlated with their components by definition. Table 7 shows the correlation numbers between the interaction terms and their components. The observed high correlation could bias the estimates and also cause instability in the parameter estimates due to increase in the size of the estimated variance. In this context, we cannot conclude that there are substitution effects between insurance variables and measures of banking or stock market development. Moreover, a substitution effect between insurance measures and private credit looks contradictory with the data after observing the positive and significant relationship between life, non-life, and total insurance (life and non-life) premiums to GDP and private credit to GDP, particularly for high-income countries (see Appendix 3). With respect to the stock market, a substitution effect would also look contradictory with the data. Appendix 3 shows a positive and significant relationship between stock market

\footnotetext{
${ }^{12}$ The negative interaction would not depend on the stage of banking sector development. The interaction term between insurance variables and private credit was interacted with three dummy variables that take the value of one if the value of the private credit to GDP ratio is lower than the $25^{\text {th }}$ percentile value of the sample, between the $25^{\text {th }}$ percentile value and $75^{\text {th }}$ percentile value, or higher than the $75^{\text {th }}$ percentile value. There were not differences in the value of the interaction term coefficient across the three different groups, which was negative and between 1.01 and 1.08.
} 
turnover and life insurance premiums to GDP, particularly for high income countries. On the other hand, the data do not show a relationship between stock market turnover and non-life insurance premiums to GDP.

Table 6: Interaction of Insurance Variables with Private Credit and Stock Market Turnover

Sample of 56 countries, 1976-2004 (5-year period observations)

Dependent Variable: Growth in real GDP per capita

Estimation Method: GMM-IV System Estimator

\begin{tabular}{|c|c|c|c|c|c|c|}
\hline & $\begin{array}{c}{[1]} \\
\text { Life insurance }\end{array}$ & $\begin{array}{c}\text { [2] } \\
\text { Non-Life insurance } \\
\end{array}$ & $\begin{array}{c}{[3]} \\
\text { (Life + Non-Life) } \\
\end{array}$ & $\begin{array}{c}\quad[4] \\
\text { Life insurance }\end{array}$ & $\begin{array}{c}{[5]} \\
\text { Non-Life insurance }\end{array}$ & $\begin{array}{c}{[6]} \\
\text { (Life + Non-Life) } \\
\end{array}$ \\
\hline \multirow[t]{2}{*}{ Constant } & $0.120^{* * *}$ & $0.137^{* \star *}$ & $0.145^{* * *}$ & $0.123 * * *$ & $0.167 * * *$ & $0.156^{* * *}$ \\
\hline & 0.000 & 0.000 & 0.000 & 0.011 & 0.000 & 0.000 \\
\hline \multirow[t]{2}{*}{ Private Credit to GDP } & $0.015^{* *}$ & 0.021 ** & $0.023^{* * *}$ & -0.002 & 0.005 & 0.004 \\
\hline & 0.032 & 0.013 & 0.000 & 0.810 & 0.379 & 0.560 \\
\hline \multirow[t]{2}{*}{ Stock Market Turnover } & $0.018^{* * *}$ & $0.031 * \star \star *$ & $0.023^{* * *}$ & $0.025 * * *$ & $0.033^{\star * *}$ & $0.026^{\star \star \star}$ \\
\hline & 0.000 & 0.000 & 0.000 & 0.000 & 0.000 & 0.000 \\
\hline \multirow[t]{2}{*}{ Insurance } & $0.764 * * *$ & $0.478 * \star *$ & $0.490^{* * *}$ & $0.232^{* * *}$ & $0.300 * * *$ & $0.194 * * \star$ \\
\hline & 0.000 & 0.000 & 0.000 & 0.011 & 0.002 & 0.000 \\
\hline \multicolumn{7}{|l|}{$\underline{\text { Insurance and interactions }}$} \\
\hline \multirow[t]{2}{*}{ Insurance * Private Credit } & $-0.893 * * \star$ & $-0.812^{\star * *}$ & $-0.545^{* * *}$ & & & \\
\hline & 0.000 & 0.002 & 0.000 & & & \\
\hline \multirow[t]{2}{*}{ Insurance * Stock Market Turnover } & & & & -0.160 * & -0.316 * & -0.120 ** \\
\hline & & & & 0.068 & 0.081 & 0.039 \\
\hline \multicolumn{7}{|l|}{ Control Variables } \\
\hline \multirow[t]{2}{*}{ Log. Initial GDP per capita } & $-0.009 * * *$ & $-0.014 * \star \star *$ & $-0.012^{* \star *}$ & $-0.011^{\star \star * *}$ & $-0.017^{\star \star * \star}$ & 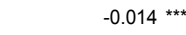 \\
\hline & 0.000 & 0.000 & 0.000 & 0.003 & 0.000 & 0.000 \\
\hline \multirow[t]{2}{*}{ Degree of openess } & $0.490^{* * *}$ & 0.551 ** & $0.517^{\text {** }}$ & $0.630 * * *$ & $0.362 *$ & 0.335 \\
\hline & 0.003 & 0.025 & 0.033 & 0.004 & 0.104 & 0.162 \\
\hline \multirow[t]{2}{*}{ Governement consumption } & $-2.494 * \star \star$ & $-1.864 * \star \star \star x$ & $-2.924 * \star \star$ & $-2.175^{\star \star \star *}$ & $-1.797^{\star \star \star *}$ & $-2.275^{\star \star \star}$ \\
\hline & 0.000 & 0.000 & 0.000 & 0.000 & 0.000 & 0.000 \\
\hline \multirow[t]{2}{*}{ Inflation } & $-0.003^{* * *}$ & $-0.003 * \star *$ & $-0.003^{* * *}$ & $-0.003^{* * *}$ & $-0.003^{* \star *}$ & $-0.003^{* * *}$ \\
\hline & 0.000 & 0.000 & 0.000 & 0.000 & 0.000 & 0.000 \\
\hline \multirow[t]{2}{*}{ Terms of trade } & $0.056^{* * *}$ & $0.045^{\star * *}$ & $0.047^{* \star *}$ & $0.044^{\star \star *}$ & $0.057^{* * *}$ & $0.050 * \star *$ \\
\hline & 0.000 & 0.000 & 0.000 & 0.000 & 0.000 & 0.000 \\
\hline \multirow[t]{2}{*}{ Human Capital Investment } & $0.044^{* * *}$ & $0.052 * * *$ & $0.052^{* * *}$ & $0.049 * \star *$ & $0.059 * * *$ & $0.054^{* * *}$ \\
\hline & 0.000 & 0.000 & 0.000 & 0.000 & 0.000 & 0.000 \\
\hline \multicolumn{7}{|l|}{ Period shifts } \\
\hline Period $81-85$ & $-0.015^{* \star *}$ & $-0.016^{* * *}$ & $-0.014^{* * *}$ & $-0.015^{* \star *}$ & $-0.015^{* * *}$ & $-0.015^{* * *}$ \\
\hline Period 86-90 & $-0.009 * * *$ & $-0.012 * \star *$ & $-0.009 * * *$ & $-0.012 * \star \star *$ & $-0.012 * * *$ & $-0.012 * * *$ \\
\hline Period 91-95 & $-0.020 * * *$ & $-0.024^{\star \star *}$ & $-0.022 * * *$ & $-0.023 * \star *$ & $-0.022 * * *$ & $-0.023^{* * *}$ \\
\hline Period $96-00$ & $-0.021 * \star *$ & $-0.027^{* * *}$ & $-0.025^{* * *}$ & $-0.026^{* * *}$ & $-0.027 * * \star$ & $-0.027^{\star \star \star}$ \\
\hline Period 01-04 & $-0.030 * * *$ & $-0.038 * * *$ & $-0.035^{* \star *}$ & $-0.037^{* * *}$ & $-0.038 * \star *$ & $-0.039 * * x$ \\
\hline Countries & 56 & 56 & 56 & 56 & 56 & 56 \\
\hline Observations & 263 & 263 & 263 & 263 & 263 & 263 \\
\hline \multicolumn{7}{|l|}{ Specification tests (p-values) } \\
\hline -Sargan test & 0.456 & 0.463 & 0.321 & 0.459 & 0.315 & 0.421 \\
\hline-2 nd. Order Correlation & 0.319 & 0.525 & 0.380 & 0.336 & 0.464 & 0.325 \\
\hline
\end{tabular}


Table 7: Correlations between insurance variables and their interactions.

\begin{tabular}{|c|c|c|c|c|c|c|}
\hline & Life & Non-Life & $\begin{array}{c}\text { Life }^{*} \\
\text { Private Credit }\end{array}$ & $\begin{array}{c}\text { Non-Life* } \\
\text { Private Credit }\end{array}$ & $\begin{array}{c}\text { Life* Stock }^{*} \\
\text { Market Turnover }\end{array}$ & $\begin{array}{l}\text { Non-Life* Stock } \\
\text { Market Turnover }\end{array}$ \\
\hline Life & 1 & & & & & \\
\hline \multirow[t]{2}{*}{ Non-Life } & 0.427 & 1 & & & & \\
\hline & 0.000 & & & & & \\
\hline Life* $^{*}$ & 0.934 & 0.381 & 1 & & & \\
\hline Private Credit & 0.000 & 0.000 & & & & \\
\hline Non-Life* & 0.599 & 0.746 & 0.693 & 1 & & \\
\hline Private Credit & 0.000 & 0.000 & 0.000 & & & \\
\hline Life* Stock & 0.547 & 0.263 & 0.502 & 0.484 & 1 & \\
\hline Market Turnover & 0.000 & 0.000 & 0.000 & 0.000 & & \\
\hline Non-Life* Stock & 0.375 & 0.444 & 0.367 & 0.604 & 0.794 & 1 \\
\hline Market Turnover & 0.000 & 0.000 & 0.000 & 0.000 & 0.000 & \\
\hline
\end{tabular}

Finally, an additional exercise was carried out by including in the growth regressions an interaction term between private credit to GDP and stock market turnover. The coefficient on the interaction term is significant but negatively signed as the previous interaction terms. Again, the individual components were significant and positively signed. This result would be showing that collinearity is playing an important role in the results previously described given that in the empirical literature it has been shown that the interaction between stock market measures and private credit is positive.

\section{Conclusions}

The goal of the present paper is to provide a systematic assessment of the impact of insurance market activity (life and non-life insurance) on economic growth. To accomplish this task we use measures of insurance premiums as a proxy of insurance activity for a set of 56 countries over the 1976-2004 period. Among the main results we have:

First, we found robust evidence of a causal relationship of insurance market activity on economic growth. Both life and non-life insurance premiums have a positive and significant effect on economic growth.

Second, we found evidence that in the case of life insurance, its impact on economic growth is driven by high-income countries only. On the other hand, in the case of non-life insurance, its impact is driven by both high-income and developing (middle and lowincome) countries. However, the results suggest that non-life insurance has a larger effect in high-income countries than in developing ones. 
Finally, the present paper does not find evidence of non-linear effects of insurance variables and positive complementarities between insurance variables and private credit to GDP and stock market turnover. However, the previous results could be due to collinearity issues. 


\section{References}

Arellano, Manuel and Stephen Bond (1991). "Some Tests of Specification for Panel Data: Monte Carlo Evidence and an Application to Employment Equations,” Review of Economic Studies 58:277-297.

Arellano, Manuel and O. Bover (1995). “Another Look at the Instrumental-Variable Estimation of Error-Components Models,” Journal of Econometrics 68:29-51.

Barro, Robert and Xavier Sala-i-Martin (1995). Economic Growth. New York: McGrawHill, Inc.

Beck, Thorsten and Ross Levine (2004). "Stock Markets, Banks, and Growth: Correlation or causality,” Journal of Banking and Finance, 28, 2004, 423-442.

Impavido, Gregorio; Alberto R. Musalem; and Therry Tressel (2003). "The Impact of Contractual Savings Institutions on Securities Markets,” The World Bank, Policy Research Working Paper 2948.

King, Robert G. and Levine, Ross (1993a). "Finance and Growth: Schumpeter Might Be Right," Quarterly Journal of Economics, August, 108(3): 717-38.

King, Robert G. and Levine, Ross (1993b). "Finance, Entrepreneurship, and Growth: Theory and Evidence," Journal of Monetary Economics, 32(3), pp. 513-42.

Levine, Ross (1998). "The Legal Environment, Banks, and Long-Run Economic Growth," Journal of Money, Credit, and Banking, August, 30(3 pt.2), pp.596-613.

Levine, Ross and Sara Zervos (1998). "Stock Markets, Banks, and Economic Growth," American Economic Review, June, 88(3), pp. 537-58.

Levine, Ross (1999). "Law, Finance, and Economic Growth", Journal of Financial Intermediation, 8(1/2), pp. 36-67.

Levine, Ross; Norman Loayza; and Thorsten Beck (2000). "Financial intermediation and growth: Causality and causes,” Journal of Monetary Economics, 46:31-77.

Levine, Ross (2004). “Finance and Growth: Theory and Evidence.” Forthcoming Handbook of Economic Growth.

Outreville, J.F. (1990). “The economic Significance of Insurance Markets in Developing Countries,” Journal of Risk and Insurance, 57(3):487-498.

Swiss Re (2005). "World Insurance in 2004: growing premiums and stronger balance sheets” No. 2. 
Skipper, Harold, Jr. (1997). "Foreign Insurers in Emerging Markets: Issues and Concerns” Center for Risk Management and Insurance, Occasional Paper 97-2.

Ward, Damian and Ralf Zurbruegg (2000). "Does Insurance Promote Economic Growth? Evidence from OECD Countries,” The Journal of Risk and Insurance, Vol. 67, No. 4, 489-506.

Webb, Ian; Martin F. Grace; and Harold D. Skipper, (2002). “The Effect of Banking and Insurance on the Growth of Capital and Output” Center for Risk Management and Insurance, Working Paper 02. 
Appendix 1: List of Countries

\begin{tabular}{|c|c|c|}
\hline High Income & Middle Income & Low Income \\
\hline $\begin{array}{l}\text { Australia } \\
\text { Austria } \\
\text { Belgium } \\
\text { Canada } \\
\text { Denmark } \\
\text { Finland } \\
\text { France } \\
\text { Germany } \\
\text { Greece } \\
\text { Iceland } \\
\text { Ireland } \\
\text { Israel } \\
\text { Italy } \\
\text { Japan } \\
\text { Korea } \\
\text { Netherlands } \\
\text { New Zealand } \\
\text { Norway } \\
\text { Portugal } \\
\text { Spain } \\
\text { Sweden } \\
\text { Switzerland } \\
\text { United Kingdom } \\
\text { United States }\end{array}$ & $\begin{array}{l}\text { Argentina } \\
\text { Brazil } \\
\text { Chile } \\
\text { China } \\
\text { Colombia } \\
\text { Costa Rica } \\
\text { Ecuador } \\
\text { Egypt } \\
\text { El Salvador } \\
\text { Indonesia } \\
\text { Jordan } \\
\text { Malaysia } \\
\text { Mexico } \\
\text { Morocco } \\
\text { Nigeria } \\
\text { Pakistan } \\
\text { Panama } \\
\text { Paraguay } \\
\text { Peru } \\
\text { Philippines, The } \\
\text { South Africa } \\
\text { Thailand } \\
\text { Trinidad and Tobago } \\
\text { Tunisia } \\
\text { Turkey } \\
\text { Uruguay } \\
\text { Venzuela }\end{array}$ & $\begin{array}{l}\text { Cote d'Ivore } \\
\text { India } \\
\text { Kenya } \\
\text { Nigeria } \\
\text { Pakistan } \\
\text { Zimbanwe }\end{array}$ \\
\hline
\end{tabular}

Classification following WDI, The World Bank. 


\section{Appendix 2: Definitions and Sources of Variables Used in the Regression Analysis}

\begin{tabular}{|c|c|c|}
\hline Variable & Definition and Construction & Source \\
\hline GDP per capita & Ratio of total GDP to total population. GDP is in 1995 PPP-adjusted US\$ & World Development Indicators (WDI), The World Bank. \\
\hline GDP per capita growth & Log difference or real GDP per capita & Author's calculation using WDI. \\
\hline Initial GDP per capita & $\begin{array}{l}\text { Initial value of ratio of total GDP to total population. GDP is in } 1995 \text { PPP- } \\
\text { adjusted US } \$\end{array}$ & Author's calculation using WDI. \\
\hline Trade openness & Log of ratio of exports and imports (in 1995 US\$) to GDP (in 1995 US\$) & WDI, The World Bank. \\
\hline Government consumption & Log of the ratio og government consumption to GDP. & WDI, The World Bank. \\
\hline Inflation rate & Annual change in CPI. & WDI, The World Bank. \\
\hline Changes in Terms of trade & Log differences of the net barter terms of trade index $(1995=100)$ & Author's calculation using WDI. \\
\hline Human capital investment & $\begin{array}{l}\text { Ratio of the total secondary enrollment, regardless of age, to the population } \\
\text { of the age group that offically correspond to that level of education. }\end{array}$ & WDI, The World Bank. \\
\hline Stockmarket turnover ratio & $\begin{array}{l}\text { Ratio of the value of total shares traded and average real market capitalization, } \\
\text { the denominator is deflated using the following method: } \\
T_{t} / P_{-} a t\left\{\left(\{0.5)^{*}\left[M_{t} / P_{-} e_{t}+M_{t-1} / P_{-} e_{t-1}\right]\right.\right. \\
\text { where } T \text { is total value traded, } M \text { is stock market capitalization, } P_{-} e \text { is end-of period CPI } \\
P_{-} a \text { is average annual } C P I\end{array}$ & $\begin{array}{l}\text { Financial Structure Database, Thorsten Beck. } \\
\text { Standard and Poor's Emerging Market Database (and } \\
\text { Emerging Stock Markets Factbook).Data on the deflators } \\
\text { (line 64M..ZF or, if not available, 64Q..ZFand annual } \\
\text { CPI (line 64.ZF)) are taken from the electronic version ofthe IFS. }\end{array}$ \\
\hline Life insurance penetration & Life insurance premium volume as a share of GDP & $\begin{array}{l}\text { Financial Structure Database, Thorsten Beck. } \\
\text { Premium data is taken from various issues of Sigma. Data on GDP } \\
\text { in local currency (lines 99B..ZF or, if not available, line 99B.CZF), }\end{array}$ \\
\hline Non-life insurance penetration & Nonlife insurance premium volume as a share of GDP & $\begin{array}{l}\text { Financial Structure Database, Thorsten Beck. } \\
\text { Premium data is taken from various issues of Sigma. Data on GDP } \\
\text { in local currency (lines 99B.ZF or, if not available, line 99B.CZF), }\end{array}$ \\
\hline Private credit by deposit money banks to GDP & $\begin{array}{l}\text { Private credit by deposit money banks to GDP, calculated using the following } \\
\text { deflation method: } \\
\left\{(0.5)^{*}\left[F_{t} / P_{-} e_{t}+F_{t-1} / P_{-} e_{t-1}\right]\right\} /\left[G D P_{t} / P_{-} a_{d}\right] \\
\text { where } F \text { is credit to the private sector, } P_{-} e \text { is end-of period CPI, and } P_{-} \text {a is } \\
\text { is average annual CPI. }\end{array}$ & $\begin{array}{l}\text { Financial Structure Database, Thorsten Beck. } \\
\text { Raw data are from the electronic version of the IMF's International Financial Statistics (IFS lines } \\
22 \text { d). Data on GDP in local currency (lines 99B..ZF or, if not available, line 99B.CZF), end-of } \\
\text { period CPI (line 64M. ZF or, if not available, 64Q..ZF), and annual CPI (line 64.ZF) are from the } \\
\text { electronic version of the IFS. }\end{array}$ \\
\hline
\end{tabular}


Appendix 3: Scatters among insurance variables, private credit and stock market turnover (all countries)
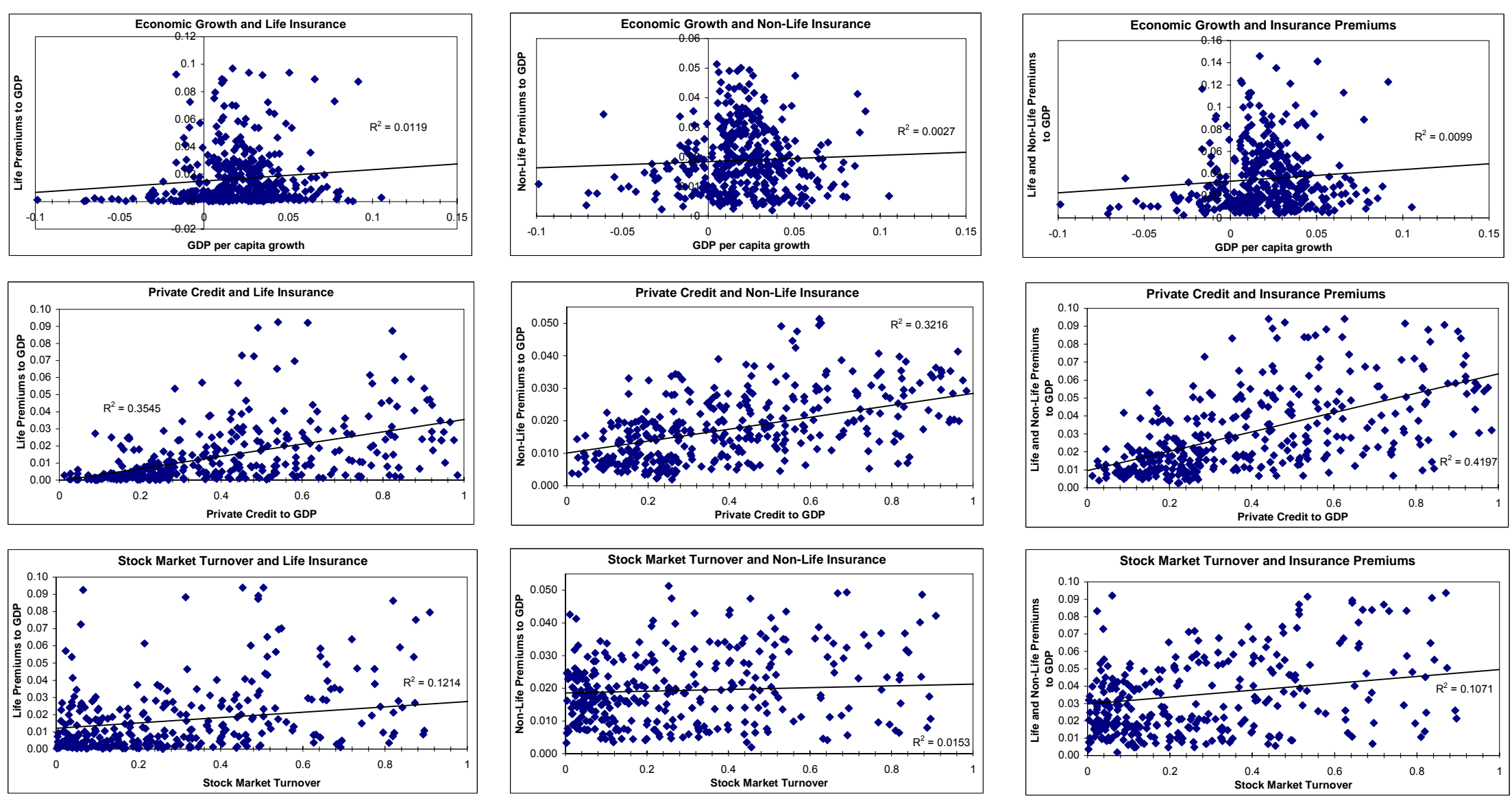